\title{
How Media Manipulates Public Opinion in Case of Wars
}

\author{
Udhava Gupta
}

\begin{abstract}
This study aimed to explore the involvement of media in shaping the opinion of the public during various wars. The research analysed three wars namely the Iraq war of 1991, the Iraq war of 2003 and the Vietnam War using secondary data from various research articles, videos and history based blogs. It was found that media played a pertinent role in not only forming the public's opinions but also in orchestrating the war itself with the help of several tactics such as either representing only half of the story based on unreliable sources or propagating "Breaking News" by using false claims and headlines. The current research also found that media indulged in selectivity of history where they chose to present only positive aspects of one side and negative things of the other whichfacilitatedthe achievement of their aim of framing the public opinion.
\end{abstract}

Index Terms - Iraq war, Vietnam war, Media, Public Opinion.

\section{INTRODUCTION}

Highlight Media has often tried to mold news in order to set its own agenda.By manipulating opinion and misleading the public with false or altered information, the media has gone from a supposedly independent estate to mouthpieces for partisan bicker. Media uses methods of "manufacturing consent" and "perception management" to control and shape our perception of world events. Jacob Hillesheim (author at Rewire.org) said: "We take political news coverage for granted today, even though most people don't understand the assumptions reporters make when writing stories or why certain stories appear in their Facebook news feed. The fact is that the news media shapes public opinion about current events in profound and unexpected ways". In ways especially pertaining to foreign policy and warfare, the media has manipulated public opinion by cherry-picking the information and presented them with deceitful tactics.

Though the media is referred to as the "liberal media", one has a hard time finding an example of major media outlets, such as The Washington Post and The New York Times, challenging the way in which the agenda setting for war is underway. Over the past five decades, officials, writers, and pundits of The Washington Post, The New York Times, CNN, and other news outlets have been reporting deceiving information regarding wars while withholding crucial information. They change the names of the countries, dates of operations, total casualties, etc. The media has a reputation of

Udhava Gupta, $12^{\text {th }}$ Student , Neerja Modi School, Jaipur exaggerating or understating the statistics of war, ranging from the bombs dropped to the blood spilled.

Propaganda is used to support wars by evoking images of nationalism, channeling fear towards enemies and using phrases to villainize nations and foreign citizens. The media is also influenced by professional public relations, covert, and overt government publications, which spread propaganda as news. The news sources, considered to be credible, can knowingly or unknowingly push political agendas. Some techniques used by government or officials with hidden agendas include paying news reporters to promote certain issues without the broadcaster being well-informed on the issue or without mention of trustworthy sources by media, governments, and officials giving contracts to public relations firms to sell a war and partial or misleading information reported as news without providing sources that might be doubtful and questionable. A great example of this is the Persian Gulf War, which highlighted a huge amount of public relations, works in action along with media's role in framing a false picture.

\section{IRAQ WAR (1991)}

Hill and Knowlton, considered the largest PR firm at the time of first Iraq war, invented the dead baby story in Iraq, using a Kuwaiti Ambassador's daughter to stand in front of cameras as a nurse to claim that Iraqi soldiers had entered a Kuwaiti hospital, removed hundreds of newborn babies from the incubators and threw them on the floor to die so that they could use those incubators to make nuclear weapons. There were many Video News Releases of this incident which were wide-spread amongst the public. With the help of the firm's expanding connections and tactics, it won public support and trust which transformed a fake news as the truth in minds of people.

This firm served as mastermind for the Kuwaiti campaign. Its activities led to it being declared as the largest foreign-funded campaign which aimed at manipulating American public opinion. The Foreign Agents Restriction Act should have exposed this propaganda campaign by law, but the Justice Department decided not to enforce it. The Emir's government commissioned H\&K to represent "Citizens for a Free Kuwait", a hideous PR group which would conceal the real role of the Kuwaiti government and its affiliation with the Bush Administration. Now the question is how did media portray this entire issue? Well, the news did not bother to examine Craig Fuller's (the man running H\&K's Washington office and a close friend of President Bush) role until the war had ended. H\&K relied on Vice-Chairman Frank 


\section{How Media Manipulates Public Opinion in Case of Wars}

Mankiewicz, who'd served as press secretary and advisor to Robert F. Kennedy and George McGovern, to communicate with the public. The firm arranged a plethora of briefings, meetings, calls and mailings aimed at editors of daily newspapers and media outlets. In these meetings/calls, the firm tried providing half and fake news about incidents to the media reporters and journalists.

Every big media event requires what reporters and journalists refer to as "the hook". That unique hook becomes the core substance of a story that makes it newsworthy, elicits strong emotional response and gets huge amount of attention and support. In case of this issue, the "hook" was created by $\mathrm{H} \& \mathrm{~K}$. This is what the baby fable (as discussed above) invented by this firm did.

There is a good example of how the George Bush's I administration pulled the American people onboard in support of the invasion of Kuwait in 1991. He was successful in manufacturing public's consent by rallying support in U.S. through the demonization of Saddam Hussein and the Armed Forces of Iraq. By claiming Hussein as the new Hitler, in various news channels, and by fabricating stories of Iraqi atrocities, Bush effectively created a strong desire amongst the American public to stop the perceived "evil" and presented war as the only option. Having manufactured consent, Bush tried to maintain this consent by restricting media and imposing censorship. The military controlled the media's movements by denying access to soldiers on the battlefield and resultantly they were dependent on official briefers and public affairs officers.

\section{IRAQ WAR (2003)}

In case of the second Iraq War (2003), the Bush II Administration claimed that Saddam Hussein tried to acquire uranium in Niger to produce Iraqi nuclear weapons. To investigate this issue, Joseph Wilson was sent as US Ambassador to Niger, who found that the accusation was devoid of evidence and facts and that the documents on which this allegation was based were forgeries. It also alleged that the aluminum tubes purchased by Iraq were destined to produce nuclear weapons fuel. The US Department of Energy and IAEA (International Atomic Energy Agency) rejected this allegation. But the media demonstrated just the first half of the story i.e. the allegations put by Bush administration with the help of bold headlines and catchy patriotism quotes so that the public can support the cause of war even if they're perplexed or uncertain about it. Since newspapers are a form of media too, this deceptive story received a boost when the New York Times devoted the lead article on the first page of its September 8, 2002 edition, to an elucidated account of the aluminum tubes, mentioning only the claims put by Bush's administration. Others in the administration referred to the Times' article as 'evidence'. This deception worked since majority of Americans believed that Iraq posed a threat to the US. According to research sources, "The LA Times poll showed striking evidence of the success of the deceptive story: ninety percent of respondents believed that Saddam Hussein was developing weapons of mass destruction".

In addition to this, Bush II Administration claimed that Iraq was affiliated with Al-Qaeda and used the media outlets to broadcast this false claim. Former government officials told the New York Times that the Bush II administration had based this claim on a declaration made by a Libyan prisoner, Ibn al Shaykh Al Libi who was sent to Egypt in January 2002 by US authorities, after being captured in Pakistan. Al Libi later said that he had made-up the claim of Iraq-Al Qaeda link to escape harsh treatment in Egypt. Democratic Senator Carl Levin showcased a February 2002 government document that had concluded that Al-Libi was a probable liar and was misleading his interrogators. The document also showed that the Defense Intelligence Agency had concluded Al-Libi as a liar. Even after being exposed to the true story, Bush used Al-Libi's allegations as solid foundation for his claim of Iraq having affiliation with Al-Qaeda. In October 2002, he said: "we've learned that Iraq has trained Al-Qaeda members in bomb making and poisons and gases" in a major speech in Cincinnati on "Iraq threat". He also stated that Saddam Hussein was manufacturing Weapons of Mass Destruction. This speech given by Bush II was broadcasted by many media outlets like CNN, CBS, etc. who paired up with the New York Times and Washington Post officials to win support of public in order to conduct a war. Bush II had addressed 500 people and amongst those many protested against his speech, but due to media's use of 'cut and edit' information, all the public was informed was about the allegations Bush II's administration had put on Iraq and why it was valid enough to invade there. According to Sean Penn, "The failure of American news media to check government distortion reached new heights when, on the eve of war, the highly respected Secretary of State Colin Powell appeared before the U.N. to make the case that there were weapons of mass destruction in Iraq". Colin Powell had the highest amount of respect amongst all people in Bush II administration and even in the U.N., according to a Gallup Poll, Colin Powell was at $63 \%$ whereas Bush II was on $24 \%$ in terms of respectability. The way Bush II's administration used Colin Powell to give a speech in front of U.N. regarding Iraq was pretty clever since they knew he's the most trustworthy and reliable person in the eyes of public. Even though Colin Powell was against the idea of a military intervention, he was compelled to give a speech in front of the U.N. where he talked about how Saddam Hussein's intentions had never changed, he was producing WMDs, he also expounded on Iraq-Al Qaeda links, showed the amount of anthrax Iraq possesses and how that is affecting American people.

Later, it turns out that the speech he gave was based on unreliable sources and false claims. But the media portrayed their callous attitude by not investigating the evidence on which the speech was based and rather publicizing how positive Colin's speech was. Aaron Brown, former CNN anchor, said then, "Secretary of State Powell brought the U.N.S.C. the administration's best evidence so far". Alan Colmes (former Fox News Channel commentator) said, "He made a wonderful presentation. I thought he made a great case for the purpose of disarmament." Sean Hannity (political commentator at Fox News) claimed Colin's evidence to be irrefutable, undeniable and incontrovertible. Such remarks made by various media anchors/commentators helped 
American news media gather huge support for war and manipulate public opinion by exposing them to false claims as true evidence. According to Norman Solomon, "At the time various news reporters thought that the case of Iraq was closed after Colin's speech, it was quite possible to analyze and debunk what he was saying."

There were international news sources and British Press raising legitimate questions about the accuracy of Powell's speech but the major US news media were near unanimous in their praise regarding it and virtually silent about the factual basis of Powell's claims. Basically, the result of all this in U.S. was the image of a good, peaceful and clean war dominated by smart technology, unreliable but portrayed reliable sources, false but claimed true evidence, and huge amount of public support for invading Iraq.

The American media atrociously took charge of framing the debate about the Iraqi government's weapons of mass destruction not as a question of whether or not they even existed but as a question of where they'd been hidden and what should be done to disarm them. According to research sources, "The New York Times led the Iraq war with Judith Miller's infamous reporting on the entire Iraq story, now claimed to be false information from dubious and untrustworthy sources, but the rest of the media fell into line with the NBC Nightly News asking, "what precise threat Iraq and its weapons of mass destruction pose to America", and Time debating whether Hussein was "making a good-faith effort to disarm Iraq's weapons of mass destruction." Reports about chemical weapons stashes were broadcasted before they were even confirmed, although headlines boldly asserted their existence as an irrefutable fact.

As a result, Iraq war was termed as the "War of Disinformation' where every false claim was publicized repeatedly by media to instill a sense of support in people's minds for war. Media channels didn't broadcast regarding why the war is taking place but if the war is inevitable or not on a scale of 100. Some would report themselves as the most trusted channel to hear in case of Iraq war such as MSNBC, but all the minutes would be used to talk about the minor, insignificant details of the war. According to Sean Penn, "the failure of mainstream news organizations to raise legitimate questions about the government's rush to war was compounded by the networks' deliberate decision to stress military perspectives before any fighting had even begun" [14] That's what we observe in case of how Bush administration rushed their decision to invade in Iraq without providing true evidence of why they wish to do so. They manufactured false claims and media helped them establish those claims as the true cause of invading Iraq in public's mind.

\section{VIETNAM WAR}

Another example of media's manipulation of public opinion about wars is the case of Vietnam War. The Vietnam War was the first television war. The emergence of television amplified the devastation to such an extent that the horror and shame became instilled in people's minds for decades to come. During the Vietnam War, reporters and photographers had an extensive amount of freedom of speech, photography and movement in South Vietnam without any censorship from the government. Unlike correspondents in World War II who had to submit their works to the inspection of the government, the reporters in Vietnam were given a rare opportunity to join military forces, observe their daily lives and write about their experience. In contrast to World War II, they used deceptive sources to write their reports that were not in agreement with one another on some affairs and also stayed unnamed. According to Hallin (Professor of Communication at UCLA), "Press was no longer the extension of government; they simply did not feel the responsibility to present news with a certain consideration for a political agenda. They gained more political independence". Due to this, media and their respective reporters, represented news after immense amount of alteration resulting in framing of public's perplexed and fake perception of the war.

One of the turning points of the war was the Gulf of Tonkin incident. On August 5, 1964, a Washington Post headline stated, "American Planes hit North Vietnam After second attack on our destroyers; Move taken to halt new aggression." That very day, the front page of the New York Times reported that President Johnson had ordered retaliatory action against gunboats and certain supporting facilities in North Vietnam after renewed attacks against American destroyers in the Gulf of Tonkin. But there was no "renewed attacks against American destroyers" or no "second attack" by North Vietnam. American journalism opened floodgates for the bloody Vietnam War by reporting official claims as absolute truths. This created a pattern of baseless claims: repetitive government lies passed on by pliant mass media leading to over 50000 American deaths and millions of Vietnamese casualties.

The official story, in fact, was that the North Vietnamese torpedo boats launched an "unprovoked attack" against a US destroyer on "routine patrol" in the Gulf of Tonkin on August 2 and that North Vietnamese PT boats followed up with a "deliberate attack" on a pair of US ships two days later. In fact, the truth was that rather than being on a routine patrol on August 2, the US destroyer Maddox was actually engaged in aggressive intelligence-gathering maneuvers- in sync with coordinated attacks on North Vietnam by the South Vietnamese navy and the Laotian air force.

This is what Norman Solomon had to say in regard to this incident: "The official story about the Gulf of Tonkin was a lie but it quickly became accepted as the absolute truth by the news media because of the press's refusal to challenge that story. This made it much easier for Congress to quickly pass the Gulf of Tonkin Resolution, which was pivotal, because it opened the floodgates to the Vietnam War." [14]

In fact, in case of the Washington Post reporting, he asked more than three decades later whether there had ever been a Post retraction of its reporting on the Gulf of Tonkin events, and he called the newspaper and eventually reached the man who had been the chief diplomatic correspondent for the paper at the time, MurreyMarder. He asked him the same question and Murrey responded by saying that there had never been any post retraction. On further questioning by Norman regarding why didn't retraction take place, he replied by saying that if the news media were going to retract its 
reporting on the Gulf of Tonkin, it would have to retract its reporting on virtually the entire Vietnam War.

The book, "The War Within: America's Battle Over Vietnam", begins with a dramatic account of the Gulf of Tonkin incidents. In an interview, author Tom Wells said that the American media described the air strikes that Johnson launched in response as merely 'tit-for-tat' whereas in reality they showcased plans the administration had already drawn up for gradually increasing its overt military pressure against the North. At the end of the entire issue, the question that arises is that why did media broadcast news filled with inaccuracies and lies. According to Wells, the answer to the above question was that "since media was extremely dependent on US government officials as the source of information and were reluctant to question official pronouncements on national security issues, we received distorted information".

The Tet Offensive is yet another pivotal occurrence in the Vietnam War. It began at the end of January 1968 and was characterized as a series of Vietcong attacks against several military crucial points and more than hundred cities and towns in South Vietnam. Though the North Vietnamese were defeated in every battle during the period, Americans were astonished by the immediate attacks that their support of the Vietnam War began to fade and was eventually lost. The reason why these attacks came as such a surprise was a national week-long holiday, Tet, an annual celebration of Vietnamese New Year. A cease-fire was declared and most significantly maintained every year prior to the Tet Offensive and it was supposed to be the same in 1968. This issue viewed as a turning point because of how media coverage changed the attitude of the public towards Vietnam War. This is how media coverage took place: after a trip to Hue during the offensive, CBS anchorman Walter Cronkite, on February 27, voiced concern about the bloody war in Vietnam predicting that it would end in stalemate. President Johnson remarked to his press secretary, "If I've lost Cronkite, I've lost Middle America" after watching Cronkite's report. In addition to this, the Wall Street Journal, which had supported the administration war effort in Vietnam Until Tet, posed the question whether the Tet offensive "made hash of our original commendable objectives?". On March 10, NBC television continued to question whether it was pointless for the US to "destroy Vietnam in order to save it" while five days later Time magazine joined the chorus in suggesting that victory in Vietnam might just be beyond the grasp of US. These claims and questions put by news media anchors helped build public opinion in the way they wanted to shape it.

During the early years of President Johnson's involvement in the war, correspondents gave reports with the statements of official, they didn't express their opinion on the matter or question the officials, theTet offensive changed this scenario. According to Hallin, "Before the Tet Offensive, 5.9 percent of news contained personal commentaries but during the following few months the number of commentaries grew to 20 percent and again lowered to 9.8 percent after Tet, but it was still higher than before the attacks".

Taking into account the change in media coverage, there were several other matters which helped manipulate public opinion about the war. Firstly, it was the deceitful, contradictory reports from ambiguous sources and the rise of commentaries from the journalist. Another issue was the media's emphasis on the devastating impact of the attacks on cities and civilians. Lastly, it was the credibility of the US government. Along with all these issues, the personal commentaries of reporters broadcasted by media also played an important role in framing public opinion. One of the most significant commentaries was made by Walter Cronkite.

Walter Cronkite, a reputable news presenter for CBS Evening News (1916-2009), was said to be "the most trusted man in America". When the Tet Offensive turned into a big issue, he was sent to Vietnam to report personally from Saigon. After giving his thorough report of the situation in Vietnam, he said that he was going to give his personal view of the war. He admitted that his speech had a great impact on public opinion. His speech was as follows:

"....To say that we are closer to victory today is to believe, in the face of the evidence, the optimists who have been wrong in the past. To suggest we are on the edge of defeat is to yield to unreasonable pessimism. To say that we are mired in stalemate seems the only realistic, yet unsatisfactory, conclusion....But it is increasingly clear to this reporter that the only rational way out then will be to negotiate, not as victors, but as an honorable people who lived up to their pledge to defend democracy, and did the best they could".

This speech turned out to be against the rules of objective journalism and it was, in some way, manipulation of the viewer. It helped frame America's opinion of war through representation of all these things by various media outlets. According to Norman Solomon, "The news media have generally bought into and promoted the notion that it's up to the President to make foreign policy decisions. This smart guy in the oval office has access to all the information, he knows more than we do, he's the commander in chief. And the American people have no major role to play, and nor should they, because after all they don't have knowledge or capability to be responsive to the real situation. That was certainly true during Vietnam War". [13]

He said so because in the case of Vietnam War as we discussed above, media kept broadcasting personal commentaries and misleading reports in order to manipulate/shape public opinion. They published whatever the President and his officials claimed which led to creation of excessive amount of confusion amongst people. This resulted in them being uninformed and at the same time they were left clueless as to which side shall they support. The end result was public supporting whatever the media and their reporters showcased on the television.

\section{CONCLUSION}

To conclude, media played the major role in causing these wars by either demeaning the other side or by altering the actual facts on which the war was based. From Presidents at the White House to administrations to American News anchors or commentators, everyone would say that they wish to establish peace in their country but on the other hand they would be bombing other countries or indulging in military 
World Journal of Research and Review (WJRR)

\section{ISSN:2455-3956, Volume-7, Issue-4, October 2018 Pages 28-32}

activities which weren't even justified till the end of war. Media would play the role of publicizing Presidents or administration or government claims in which they'll be using phrases like "U.S. is on the edge of war", "We all believe Iraq possesses WMDs", "America is in deep danger and if we truly love our country, we shall put a step forward and do something in favor of our nation", etc. Such phrases invoke negative thoughts in people's minds and helps media manipulate their opinion. Even if the public is against any claims put by higher powers, when any of them say that "WE BELIEVE THAT.." , people alter their thoughts in favor of what they were initially against.

As discussed in above examples, media uses various tactics to achieve high level of manipulation of public opinion. It would pair up with various newspaper journalists and present a pre-packaged video sent to it by Presidents/Bush Administration/etc. Either they'll represent half of the story based on unreliable sources or they'll give "Breaking News" by using false claims and headlines. They also indulge in selectivity of history where they choose to present only positive things of one side and negative things of the other side. Such tactics help them achieve their aim of framing public opinion.

All these things help media accomplish their mission of manipulating public opinion. At the end, I'd like to quote what Norman Solomon said about media's focus: "A big problem with the media focus is that it sees the war through the eyes of the Americans, through the eyes of occupiers, rather than those who are bearing the brunt of the war in human terms."

\section{ACKNOWLEDGMENT}

This research was partially supported by Mrs. Rachna Gangwar, Professor, TAPMI school of business, Manipal University, Jaipur. I thank my colleagues from various institutions of Jaipur, Spain, Massachusetts, and New York for providing meaningful insights through spirited discussions.

I thank Meesha Gupta for taking out time from her hectic schedule at Union College, New York and helping me gain a better understanding of research and facilitated my growth as a researcher.

I would also like to show my gratitude to Mrs. Shilpa Gupta, for being my mentor and research guide throughout the arduous process of research and publication.

My acknowledgments would be incomplete without expressing gratitude to my alma mater, Neerja Modi School, Jaipur which has been the pillar of my knowledge over these years.

\section{REFERENCES}

[1] www.globalresearch.ca/faking-it-how-the-media-manipulates-the-wor ld-into-war/5336838.

[2] "Global Issues : Social, Political, Economic and Environmental Issues That Affect Us All." - Global Issues, www.globalissues.org/

[3] "Media Role in The Vietnam War." The Vietnam War, thevietnamwar.info/media-role-Vietnam-war/

[4] Michael R. Gordon and Judith Miller. "THREATS AND RESPONSES: THE IRAQIS; U.S. SAYS HUSSEIN INTENSIFIES QUEST FOR A-BOMB PARTS." The New York Times, The New $\begin{array}{lllll}\text { York } & \text { Times, } & 8 & \text { Sept. }\end{array}$ www.nytimes.com/2002/09/08/world/threats-responses-iraqis-us-sayshussein-intensifies-quest-for-bomb-parts.html.

[5] "THREATS AND RESPONSES: THE IRAQIS; U.S. SAYS HUSSEIN INTENSIFIES QUEST FOR A-BOMB PARTS.” The New York Times, The New York Times, timesmachine.nytimes.com/timesmachine/2002/09/08/781878.html?p ageNumber $=1$.

[6] "30-Year Anniversary: Tonkin Gulf Lie Launched Vietnam War." FAIR, $21 \quad$ Mar. 2018, fair.org/media-beat-column/30-year-anniversary-tonkin-gulf-lie-launc hed-vietnam-war/.

[7] "Media, Propaganda and Vietnam." - Global Issues, www.globalissues.org/article/402/media-propaganda-and-vietnam\#Me diaandtheWar.

[8] www.globalresearch.ca/iraq-manipulating-the-evidence-to-start-a-war /1976.

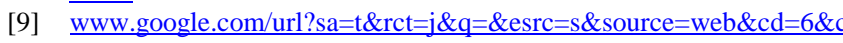
$\mathrm{ad}=\mathrm{rja} \& u a c t=8 \& v e d=0$ ahUKEwj4-6uzpZvbAhUJzFMKHXmND_cQ FghiMAU\&url=https $\% 3 \mathrm{~A} \% 2 \mathrm{~F} \% 2 \mathrm{Ftheses.cz} \% 2 \mathrm{Fid} \% 2 \mathrm{Fh} 0 \mathrm{uo} 3 \mathrm{z} \% 2 \mathrm{FB}$ achelor Thesis Hana Cihankova.pdf\&usg=AOvVaw0feNYuvTj0tLj GcY4FQta.

[10] AmericanRhetoricOrig. "George W. Bush - Cincinnati Speech on Irac Threat." YouTube, $\quad$ YouTube, $20 \quad$ May 2017 www.youtube.com/watch?v=iusLiSEsTOk.

[11] monkeyt033. "Collin Powell Vial of Anthrax Iraq War Lies.” YouTube, $\begin{array}{lll}\text { YouTube, } & 26 & \text { Sept. }\end{array}$ www.youtube.com/watch?v=jV5Ggfn9PYM.

[12] M, Jessica. "Colin Powell: Examining a Key Player in the Bush Administration.” Inquiries Journal, Elon Journal of Undergraduate Research in Communications, 1 May 2010 www.inquiriesjournal.com/articles/251/colin-powell-examining-a-key -player-in-the-bush-administration.

[13] TruthTVIdaho1. "War Made Easy Part 15 YouTube." YouTube, YouTube, 8 Feb. 2012, www.youtube.com/watch?v=fJWyjofIKPM.

[14] TruthTVIdaho1. "War Made Easy Part 45 YouTube." YouTube, $\begin{array}{llll}\text { YouTube, } & 8 & \text { Feb. } & \text { 2012, }\end{array}$ www.youtube.com/watch? $=2 \mathrm{~g} 77 \mathrm{VPg} 0 \mathrm{QEw} \& \mathrm{t}=344 \mathrm{~s}$.

[15] TruthTVBurmaMyanMar. "War Made Easy Part $5 \quad 5$ YouTube."YouTube, YouTube, 19 Jan. 2012, www.youtube.com/watch?v=klBfIr7-Rzw.

[16] TruthTVIdaho1. "War Made Easy Part 35 YouTube." YouTube, YouTube, 8 Feb. 2012, www.youtube.com/watch?v=pM538pUwLFQ.

[17] TruthTVIdaho1. "War Made Easy Part 25 YouTube." YouTube, YouTube, 11 Dec. www.youtube.com/watch?v=-X1xGO1bmQE\&t=619s.

[18] "How the Media Shapes Public Opinion of War." Rewire, Rewire, 7 Aug. www.rewire.org/pbs/vietnam-war-media-shapes-public-opinion/.

[19] "Bush Speech in Cincinnati." Democracy Now! www.democracynow.org/2002/10/8/bush speech in cincinnati. 